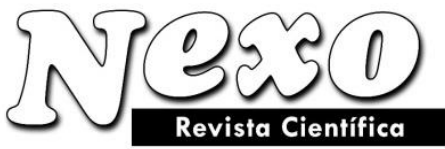

ISSN-E 1995-9516

Universidad Nacional de Ingeniería COPYRIGHT @ (UNI). TODOS LOS DERECHOS RESERVADOS

http://revistas.uni.edu.ni/index.php/Nexo

https://doi.org/10.5377/nexo.v34i06.13149

\title{
Rationing of fuel consumption based on identification of rolling stock modes
}

\section{Clasificación del consumo de combustible con base a la identificación de los modos de material rodante}

\author{
Aleksandr Mitrofanov, P. Karpov, Andrey Peshkov \\ Samara State University of Railway Transport. Samara, Russia. \\ *Corresponding author E-mail: almit77@ mail.ru
}

(recibido/received: 22-septiembre-2021; aceptado/accepted: 02-diciembre-2021)

\begin{abstract}
The article presents the results of a study of innovative technology on improving the rationing of diesel fuel consumption on rolling stock in the railway industry. As an object of research, fuel consumption was studied on a Automotrisa diesel editing - ADE-1, which is used in the electrification and power supply facilities of the Transenergo Directorate. Motorized carriage loading transport (MLT - 6), which is used in the economy of the track. On the basis of a number of regulatory documents of the Russian Railways company, the Samara State University of Railway Transport was entrusted with the analysis of the efficiency of fuel consumption of SSPS on these types of rolling stock at one of the railway landfills. The special selfpropelled rolling stock of the Russian Railways company was studied as an object of research. The method of forming fuel consumption standards by identifying the actual values of fuel consumption and indicators of rolling stock operating modes is considered. The statistical methods used in the research allow us to set the rate of consumption in the range of $8 \%$ of the actual flow rate. Based on the use of the obtained fuel consumption rate, a method for identifying and evaluating the level of unauthorized fuel overspendings (draining) is provided.
\end{abstract}

Keywords: Fuel Consumption; Predicted fuel consumption; Special self-propelled rolling stock; Work modes of SSRS operation.

\section{RESUMEN}

El artículo presenta los resultados de un estudio de tecnología innovadora para mejorar el racionamiento del consumo de combustible diesel en el material rodante de la industria ferroviaria. Como objeto de investigación, se estudió el consumo de combustible en una edición diesel Automotrisa - ADE-1, que se utiliza en las instalaciones de electrificación y suministro de energía de la Dirección de Transenergo. Transporte de carga en carro motorizado (MLT - 6), que se utiliza en la economía de la vía. Sobre la base de una serie de documentos reglamentarios de la compañía de ferrocarriles de Rusia, se encomendó a la Universidad Estatal de Transporte Ferroviario de Samara el análisis de la eficiencia del consumo de combustible de SSPS en este tipo de material rodante en uno de los vertederos ferroviarios. El material rodante autopropulsado especial de la empresa Russian Railways fue estudiado como objeto de investigación. Se considera el método de formación de estándares de consumo de combustible mediante la identificación de los valores reales del consumo de combustible y los indicadores de los modos de funcionamiento del material rodante. Los métodos estadísticos utilizados en la investigación nos permiten 
establecer la tasa de consumo en el rango del $8 \%$ de la tasa de flujo real. Sobre la base del uso de la tasa de consumo de combustible obtenida, se proporciona un método para identificar y evaluar el nivel de gastos excesivos de combustible no autorizados (drenaje).

Palabras claves: El consumo de combustible; Consumo de combustible previsto; Material rodante autopropulsado especial; Modos de trabajo de operación SSRS.

\section{INTRODUCTION}

The task of assessing the reasonable fuel consumption and evaluating the efficiency of its use in the production and economic activities of the Russian Railways Company is relevant at all stages of the life cycle of special self-propelled rolling stock (SSRS). As an object of research, fuel consumption was studied on a Automotrisa diesel editing - ADE-1, which is used in the electrification and power supply facilities of the Transenergo Directorate. Another type of rolling stock under study, which significantly differs in operating modes, is the Motorized carriage loading transport (MLT -6), which is used in the economy of the track.

On the basis of a number of regulatory documents of the Russian Railways company, the Samara State University of Railway Transport was entrusted with the analysis of the efficiency of fuel consumption of SSPS on these types of rolling stock at one of the railway landfills. One of the ways to improve the efficiency of fuel consumption is to adequately normalize it and monitor the operating modes of the SSPS in case of unauthorized fuel consumption.

Updating these directions is possible only when digitalizing the processes of actual fuel consumption and using methods of statistical construction of fuel consumption standards that are adequate for the type of rolling stock, types of work, and distance of infrastructure construction objects. The fuel consumption standards used should improve fuel efficiency and identify the modes of unauthorized fuel consumption.

\section{METHODOLOGY}

The solution to the problem of diesel fuel rationing was tested on the basis of the use of data on fuel consumption accounting on the SSPS of the company "Russian Railways" of two types:

- Autotrisa diesel editing-ADE-1, used in the electrification and power supply facilities of the Transenergo Directorate;

- Motorized carriage loading transport - MLT-6, used in the economy of the track.

Studies on fuel consumption were evaluated during the normal operation of the SSPS in its normal modes: ( - hour working mode); ( - hour idling mode); ( - hour transport mode). As automation devices, "KVART" kits developed by JSC "Electromechanika" were used (http://www.elmeh.ru), with which the SSPS was equipped.

The sum of all modes of operation of the SSPS is determined by the operating time -hour in total mode.

The method of fuel rationing used in JSC "Russian Railways" SSPS does not provide for the use of indicators in the transport mode. In this case, the indicator of the fuel consumption rate (Norma), $\mathrm{kg}$ can be estimated with an error.

In order to improve the accuracy of the assessment of fuel consumption rates on the SSPS, the authors proposed to conduct it by identification methods. In the proposed methodology, the fuel consumption rate 
indicator $\boldsymbol{B}_{\boldsymbol{j}}^{\boldsymbol{N}}$ is formed on the basis of monitoring the actual fuel $\boldsymbol{B}_{\boldsymbol{j}}^{\boldsymbol{F}}$ consumption during SSPS trips. At the same time, the values of $m$ operational factors $\boldsymbol{X}_{\boldsymbol{9}}$ that affect the level of actual fuel consumption are digitized $\boldsymbol{B}_{\boldsymbol{j}}$. The equation that relates actual fuel consumption to operational factors is presented in a general form:

$$
\boldsymbol{B}_{j}^{F}=\boldsymbol{A}\left(\boldsymbol{X}_{э_{1}}, \boldsymbol{X}_{э_{2}}, \ldots, \boldsymbol{X}_{\vartheta_{i}}, \ldots \boldsymbol{X}_{э_{m}}\right)+\xi
$$

Where $\boldsymbol{A}$ is the operator of the relationship between operational factors $\boldsymbol{X}_{\boldsymbol{J}}$ and actual fuel $\boldsymbol{B}_{\boldsymbol{j}}^{\boldsymbol{F}}$ consumption;

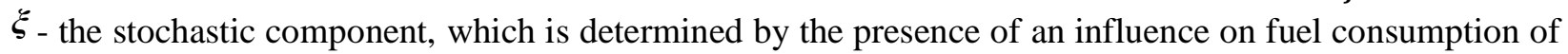
not taken into account operational factors.

The factors that can be used in equation (1) include the indicators that are studied in (Abas et al., 2017; Association of American Railroads, 2014; Capuano et al., 2017; Gritsenko et al., 2021; Mitrofanov et al., 2017, 2020; Rymaniak et al., 2019; Tshizanga et al., 2017). The indicator that is advisable to use in this equation should first of all include the mileage indicator SSPS-Run. After the stage of identifying the nature and parameters of the operator of the relationship $\boldsymbol{A}$ and monitoring the values of the selected operational factors $\boldsymbol{X}_{\boldsymbol{\theta}}$, it is possible to calculate the values of the fuel consumption rate $\boldsymbol{B}_{j}^{N}$ based on the expression:

$$
B_{j}^{N}=A\left(X_{э_{1}}, X_{\ni_{2}}, \ldots, X_{\vartheta_{i}}, \ldots X_{э_{m}}\right)+\xi
$$

A significant advantage of the identification methodology for assessing the fuel consumption rate in comparison with those used in the company "Russian Railways" is the ability to configure the operator of the relationship $\boldsymbol{A}$ for a specific type of SSPS, for a specific type of work performed, for work areas. To increase the adequacy of the identified operator $\boldsymbol{A}$, it is possible to use both linear and nonlinear types of operators.

With the linear nature of the relationship between the operator and the factors equation (2) should be represented as a regression equation of the form:

$$
\boldsymbol{B}_{j}^{N}=a_{0}+b_{1} \cdot \boldsymbol{X}_{\jmath_{1}}+b_{2} \cdot \boldsymbol{X}_{э_{2}}+\ldots+b_{i} \cdot \boldsymbol{X}_{\boldsymbol{s}_{i}}+\ldots+b_{m} \cdot \boldsymbol{X}_{\boldsymbol{э}_{m}}+\xi
$$

where is the free part of the regression equation; $b_{1}, b_{2}, \ldots b_{i}, \ldots b_{m}$ - the parameters of the equation for operational indicators that "explain" fuel consumption.

\section{LITERATURE REVIEW}

Areas of research that consider the efficiency of fuel consumption from different angles and approaches to its rationing can be demonstrated by the examples of a number of sources. There are several approaches to monitoring the assessment of the efficiency of diesel fuel consumption. The first and most developed approach to estimating fuel consumption is the introduction of hardware and software tools for monitoring and rationing fuel supply at stationary vehicle refueling facilities (Association of American Railroads, 2014). Another important area for evaluating the efficiency of fuel consumption is its monitoring in the conditions of monitoring the dynamics of the technical condition of special rolling stock, for example, in the conditions of changes in the state and scheme of the engines of the rolling stock. As this method of reducing fuel consumption, the regulation of the operating modes of the SSPS is used. So a widespread method of regulation is to turn off part of the cylinders of a diesel engine during operation. With this method of increasing efficiency, fuel consumption can be reduced in the range from $4 \%$ to $30 \%$ (Abas et al., 2017). 
The specific environmental indicators for assessing the efficiency of fuel consumption can be attributed to the method of monitoring the indicators of SSPS engine exhausts and environmental pollution indicators (Capuano et al., 2017; Gritsenko et al., 2021; Tshizanga et al., 2017). In the works of this direction, the operational and emission characteristics of an engine running on both diesel fuel and gas-engine mixtures are studied. There are known studies to evaluate the efficiency of a diesel engine in a dual-fuel mode of operation. The use of hydrogen gas in diesel engines is a promising direction for improving efficiency. The overall efficiency of the power plant can reach an increase of 30\% (Rymaniak et al., 2019). The direction of rationing of diesel fuel consumption should include the materials of the work and publications (Mitrofanov et al., 2020) of the authors of this article. This publication discusses improving the efficiency of diesel fuel consumption when equipping rolling stock with sensors and automated monitoring systems.

\section{RESULTS}

The analysis of the results of monitoring the fuel consumption modes of the ADJ-1 motor vehicle was carried out based on the results of 45 trips over a period of three months (Table 1). According to the available data, graphs of fuel consumption (Fact), kg. of operational indicators of the SSPS mileage - Run km per trip, and the total operating time of the ADJ - 1 were constructed (Figure 1).

Table 1. Available data on actual and regulatory fuel consumption of SSRS ADJ-1.

\begin{tabular}{|c|c|c|c|c|c|c|}
\hline Date & $\begin{array}{l}\text { (Htot) } \\
\text { hour in } \\
\text { total, } h\end{array}$ & Run, km & $\begin{array}{l}(\text { Hwm), hour } \\
\text { working } \\
\text { mode, } h\end{array}$ & $\begin{array}{l}\text { (Him) hour } \\
\text { idling mode, } \\
\text { h }\end{array}$ & $\begin{array}{l}(\text { Htrm }) \\
\text { hour } \\
\text { transport } \\
\text { mode, h }\end{array}$ & $\begin{array}{l}\text { Fuel } \\
\text { Consumption } \\
\text { (Fact), kg }\end{array}$ \\
\hline 01.04.2019 & 3 & 14 & - & - & - & 176 \\
\hline 02.04.2019 & 5 & 15 & - & - & - & 30 \\
\hline 03.04.2019 & 5 & 24 & - & - & - & 30 \\
\hline 04.04 .2019 & 4 & 1 & $-\bar{*}$ & - & - & 31 \\
\hline 25.06.2019 & 7 & 107 & 0 & 0 & - & 63 \\
\hline 27.06 .2019 & 6 & 107 & 0 & 0 & - & 57 \\
\hline 28.06.2019 & 3 & 3 & 0 & 0 & - & 25 \\
\hline
\end{tabular}

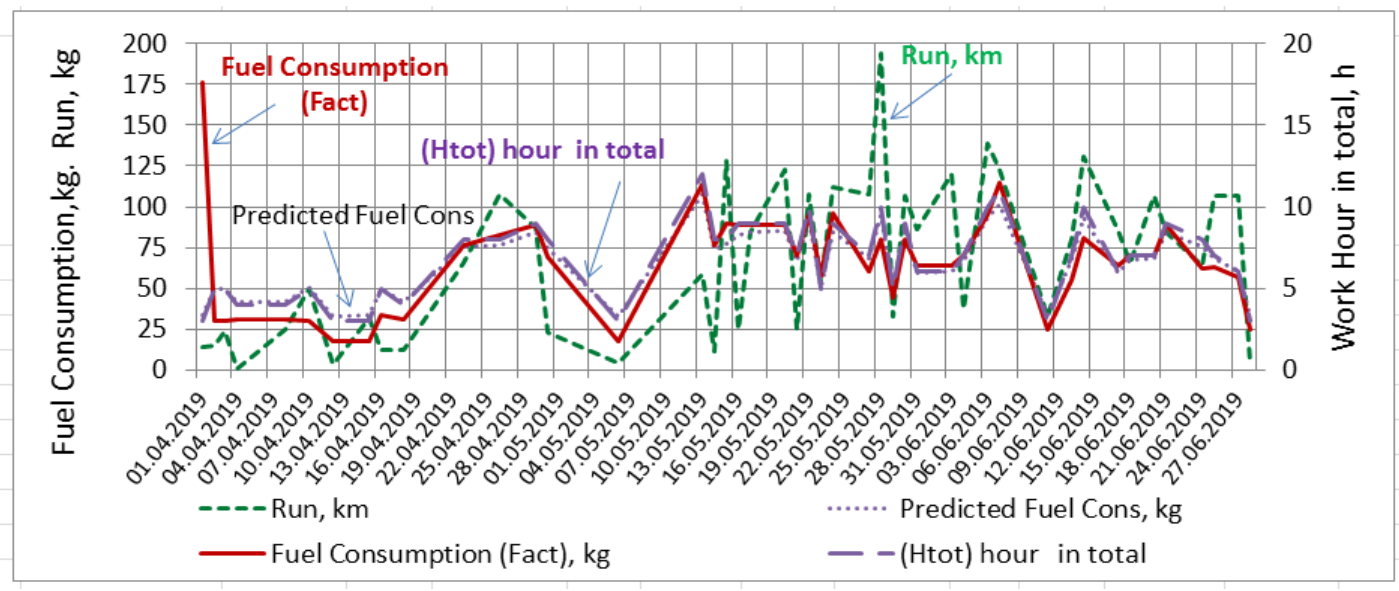

Figure 1. Fuel values and modes of ADE-1. 
Visual express analysis of the fuel consumption graph (Fact), $\mathrm{kg}$ shows an abnormal increase in values in the period 01.04.2019 with insignificant values of the hour in total (Htot) equal to 3 hours and with an insignificant mileage of $14 \mathrm{~km}$.

Statistical analysis showed that fuel consumption is significantly affected by the type of specialized selfpropelled rolling stock used, for the AMD-1 highway: the average diesel fuel consumption per trip is 64.4 $\mathrm{kg}$, the standard deviation is $31.4 \mathrm{~kg}$, and the coefficient of variation is $49 \%$. The average mileage per trip is $65.6 \mathrm{~km}$ with a standard deviation of $47.4 \mathrm{~km}$. The coefficient of variation is $72 \%$. The average amount of running hours consumed per trip is 6.7 engine hours with a standard deviation of 2.4 engine hours, which forms a coefficient of variation of $36 \%$.

Based on previous studies (Mitrofanov et al., 2017), it was found that for more accurate fuel consumption rationing, it is advisable to construct a model based on a multivariate equation of the form (3). To normalize the fuel consumption (Norm), $\mathrm{kg}$ indicator by the identification method in the expression format (3), the STATISTICA program was used. In Figure 2 the results of the graphical construction of the two-factor fuel consumption model AME-1 are presented.

The upper part of the graph shows a regression equation that allows to build the plane of fuel consumption (Norm) values. From the nature of the constructed plane, it can be seen that significant changes in the output indicator depend mainly on change in the indicator of the total operating time - hour in total (Htot) and practically do not depend on the dynamics of the run. In Figure $2 b$ the results of assessing the adequacy of the obtained model by the value of the multiple correlation coefficient $\mathrm{R}=0.65$ are presented. This level is not significant, but it exceeds the limit of the significance level $\mathrm{Rgr}=0.4$. The second column of the table Figure $2 \mathrm{~b}$ shows the partial correlation coefficients of the performance indicators of the SSPS. So the correlation coefficient of the total operating time-hour in total (Htot) is $\mathrm{R}=0.63$, which determines the significant slope of the plane in Figure 2a when this indicator is varied. The correlation coefficient of the Run indicator is $\mathrm{R}=0.037$, which explains the absence of the plane slope in Figure $2 \mathrm{a}$ when this indicator is varied.

Thus, for the tasks of rationing the fuel consumption (Norm) values for the ADE-1 vehicle, the total operating time is hour in total (Htot). Figure 1 shows a graph of Predicted Fuel Consumption, kg, which should be used as the desired indicator of the normalized values of fuel consumption (Norm). The error in generating fuel consumption (Norma) values relative to the actual values is $22 \%$.

The low degree of adequacy of the AME-1 rationing model is primarily determined by the lack of data on the time of operating modes: Hwm-hour working mode; Him-hour idling mode; Htrm-hour transport mode (Table 1). 


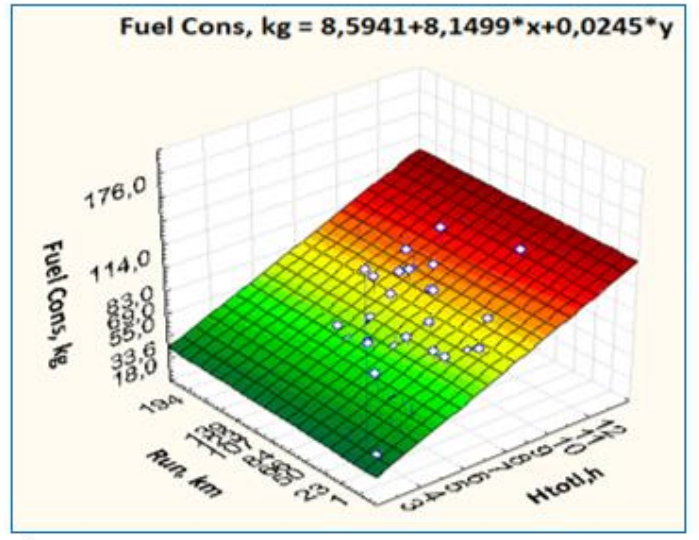

a)

\begin{tabular}{|c|c|c|c|c|c|c|}
\hline \multirow[b]{2}{*}{$N=45$} & \multicolumn{6}{|c|}{$\begin{array}{l}\text { Regression Summary for Dependent Variable: Fuel Cons, kg (Sp } \\
R=, 65656127 \mathrm{R} ?=, 43107270 \text { Adjusted } R ?=, 40398093 \\
F(2,42)=15,912 p<, 00001 \text { Std. Error of estimate: } 24,269\end{array}$} \\
\hline & Beta & $\begin{array}{l}\text { Std.Err. } \\
\text { of Beta }\end{array}$ & B & $\begin{array}{c}\text { Std.Err. } \\
\text { of B }\end{array}$ & $t(42)$ & p-level \\
\hline Intercept & & & 8,594053 & 11,14225 & 0,771303 & 0,444845 \\
\hline Htotl,h & 0,630916 & 0,158390 & 8,149931 & 2,04602 & 3,983311 & 0,000265 \\
\hline Run, km & 0,036980 & 0,158390 & 0,024532 & 0,10507 & 0,233476 & 0,816526 \\
\hline
\end{tabular}

b)

Figure 2. Identification of the parameters of the two-factor fuel consumption model AME-1 (a) graph, (b) of the regression factor B.

A more complete nature of the data was obtained when studying the dependences of fuel consumption and operating modes on the MLT - 6 types SSPS. The analysis was based on monitoring data on forty-one trips over a period of about three months in 2019 (Table 1). As a result of using the identification form of the model presented above, a graph of the actual fuel consumption (Fact), kg. and one operational indicator of the SSPS mileage - Run, km per trip (Figure 1) was constructed based on the expression (3).

Table 2. Data on actual and regulatory fuel consumption of SSPS MLT-6.

\begin{tabular}{|c|c|c|c|c|c|c|}
\hline Date & $\begin{array}{l}\text { (Htot) } \\
\text { hour in } \\
\text { total, } h\end{array}$ & Run, km & $\begin{array}{l}(\text { Hwm }) \text {, hour } \\
\text { working } \\
\text { mode, } h\end{array}$ & $\begin{array}{l}\text { (Him) hour } \\
\text { idling mode,h }\end{array}$ & $\begin{array}{l}(\text { Htrm }) \\
\text { hour } \\
\text { transport } \\
\text { mode, } h \\
\end{array}$ & $\begin{array}{l}\text { Fuel } \\
\text { Consumption } \\
\text { (Fact), kg }\end{array}$ \\
\hline 01.04.2019 & 9 & 50 & 6 & 1 & 2 & 92 \\
\hline 02.04 .2019 & 10 & 100 & 6 & 1 & 3 & 103 \\
\hline 03.04.2019 & 8 & 30 & 6 & 1 & 1 & 81 \\
\hline 04.04 .2019 & 11 & 150 & 7 & $\begin{array}{l}1 \\
* * *\end{array}$ & 3 & 114 \\
\hline 26.06 .2019 & 9 & 250 & 4 & 1 & 4 & 92 \\
\hline 29.06 .2019 & 6 & 15 & 5 & 1 & 0 & 60 \\
\hline 30.06 .2019 & 18 & 20 & 6 & 1 & 0 & 236 \\
\hline
\end{tabular}

Statistical analysis of fuel consumption of the MLT - 6 type showed that the average diesel fuel consumption per trip is $89.5 \mathrm{~kg}$, the standard deviation is $23.4 \mathrm{~kg}$, the coefficient of variation is $26.1 \%$. The average mileage per trip is $69.5 \mathrm{~km}$ with a standard deviation of $41.8 \mathrm{~km}$. The coefficient of variation is $60 \%$. The average amount of engine hours consumed per trip is 8.2 engine hours with a standard deviation of 2.2 engine hours, which forms a coefficient of $30 \%$ variation. Visual express analysis of the fuel consumption graph (Fact), kg shows first of all the presence of a number of abnormal values in the periods of 16.06.2019, 25.06.2019, 30.06.2019. At the same time, the values of the operating time and mileage of the SSPS at these times differ slightly from their average values. Thus, the visual construction of the values of operational indicators allows to identify potentially suspicious periods of the SSPS operation, during which unauthorized consumption - "draining" of fuel can be observed. Not only the fact of cases, but also the quantitative assessment of the sizes of unauthorized fuel consumption is proposed to be carried out using the method of statistical analysis-the construction of regression dependencies (Figure 4a). 
Thus, the construction of fuel consumption (Fact) dependences on the operating indicator of the total operating time $H_{\text {totm }}$ - hour in total mode showed an excess of up to $300 \%$ of fuel waste relative to its average consumption values $(100 \mathrm{~kg})$ at the indicator value $H_{\text {totm }}=10$ hours. The presence of a significant correlation coefficient $\mathrm{R}=0.71$ was established.

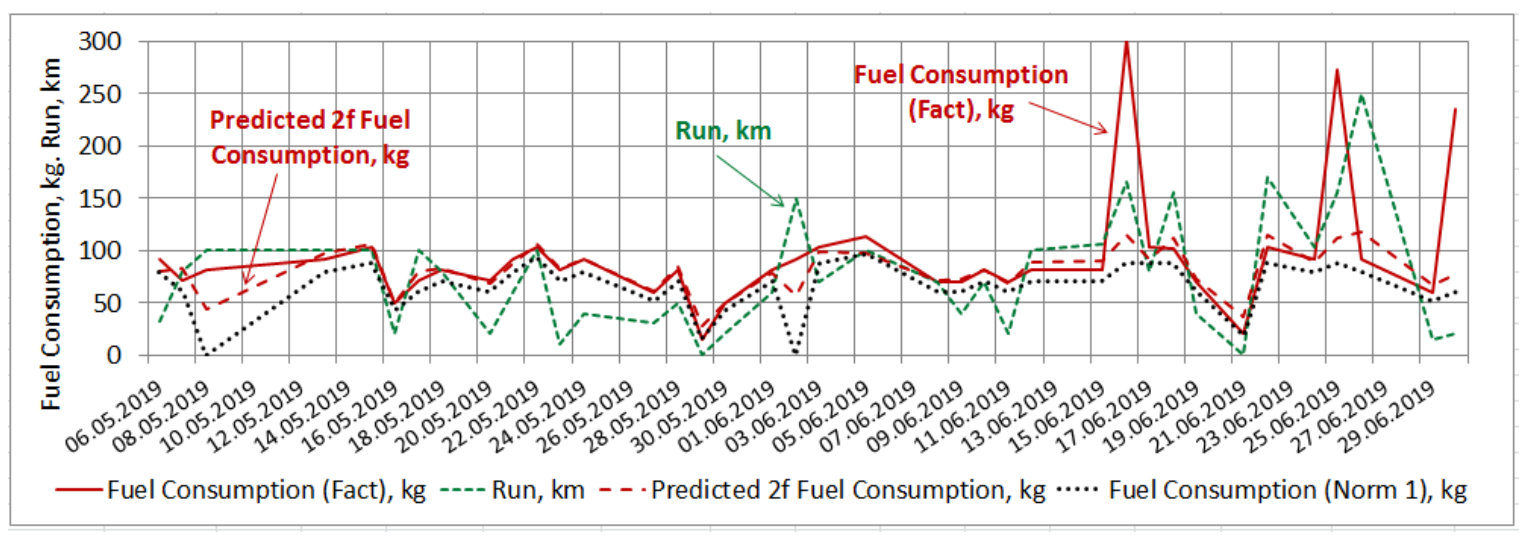

Figure 3. Fuel values and modes of MLT-6.

This allows for a specific type and area of works to identify the values of the parameters of the one-factor regression equation and use the equation to normalize the fuel consumption (Norma) indicators at known planned values of the total number of hours of work of the SSPS ( hour in work total).

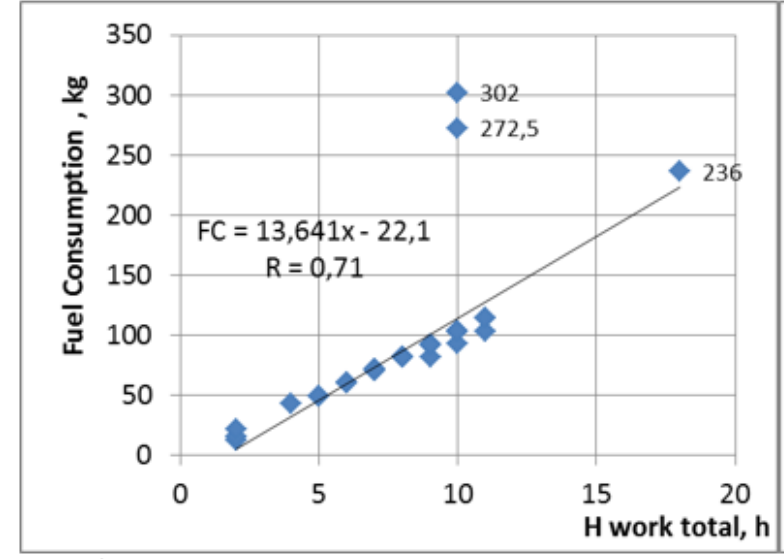

a)

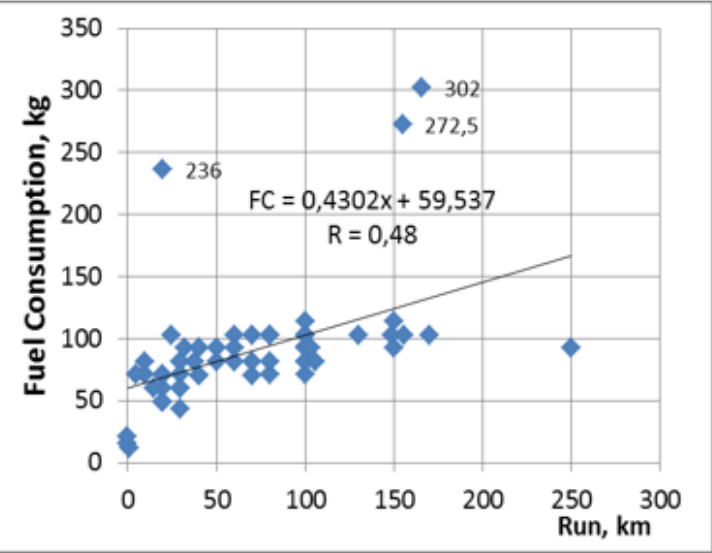

b)

Figure 4. Results of statistical fuel consumption processing MLT- 6: a) type of regression relationships from Htot hour in work total b) type of regression relationships from Run, $\mathrm{km}$.

To account for the dependence of fuel consumption (Fact) on the distance of the works site, it is advisable to establish a statistical dependence on the mileage indicator Run, $\mathrm{km}$ (Figure 4b). The analysis of the data in Table 2 shows a significant correlation between these indicators. The correlation coefficient is $\mathrm{R}=0.48$, which allows to use the run, $\mathrm{km}$ indicator to refine the fuel rationing indicators.

In Figure 4b, fuel consumption (Fact) emissions of 300, 272.5 are observed at run, km mileage values of $150,160 \mathrm{~km}$, which also differs significantly from the average consumption values. Moreover, the remoteness of these indicators distorts the accuracy of identifying the parameters of the regression equation. Thus, the exclusion of these "outlier" points from the analysis allows to adjust the value of the coefficients of the regression equation by $20 \%(\mathrm{FC}=0.3453 \mathrm{x}+58.87)$ and increase its adequacy $(\mathrm{R}=0.65)$. Based on the 
constructed one-factor regression model, it is possible to estimate the increase in fuel consumption with an increase in the distance of the objects of the SSPS operation. Analysis of the effect of idle operation modes - hour idling mode (Him) on fuel consumption does not significantly affect fuel consumption $(\mathrm{R}=0.25)$.

Figure 5 shows the results of identifying the parameters of the MLT - 6 fuel consumption models when using various operating modes based on the STATISTICA program.

In Figure 5abc the fourth columns show the coefficients (B) of the models when using:

a) a three-factor model when working hours in the following modes are used as factors: hour working mode( Hwm), hour idling mode (Him), hour transport mode (Htrm).

The multiple correlation coefficient that characterizes the adequacy of the model is $R=0.899$. At the same time, the idle mode-Him is defined as insignificant, since the p-level indicator at the Him indicator is the highest level (0.005989) and is recommended for the extraction from the equation;

b) the two-factor model when using the operating hours as factors: hour working mode( Hwm), hour transport mode (Htrm) and without taking into account the idle mode (Him). The multiple correlation coefficient decreased and is $\mathrm{R}=0.888$.

c) a two-factor model when using the hours of operation as factors: hour working mode (Hwm) and the mileage run indicator, expressed in kilometers. The adequacy of the model, which is characterized by a multiple correlation coefficient, is the highest and is $\mathrm{R}=0.925$.

Thus, to normalize the values of fuel consumption (Norma) in the operating conditions of the MLT - 6 motor carrier, the most adequate model in the study area is the Predicted Fuel Consumption model, kg presented in Figure 5c. The implementation of this indicator is shown in Figure 3. The error in generating fuel consumption (Norma) values relative to the actual values does not exceed $8 \%$. 


\begin{tabular}{|c|c|c|c|c|c|c|}
\hline \multirow[b]{2}{*}{$N=41$} & \multicolumn{6}{|c|}{$\begin{array}{l}\text { Regression Summary for Dependent Variable: Fuel Consumption } \\
R=, 89909434 \mathrm{R} ?=, 80837063 \text { Adjusted } R ?=, 79283311 \\
F(3,37)=52,027 p<, 00000 \text { Std. Error of estimate: } 10,642\end{array}$} \\
\hline & Beta & $\begin{array}{l}\text { Std.Err. } \\
\text { of Beta }\end{array}$ & B & $\begin{array}{c}\text { Std.Err. } \\
\text { of B }\end{array}$ & $t(37)$ & p-level \\
\hline Intercept & & & 28,2564 & 6,115374 & 4,62056 & 0,000045 \\
\hline Fact (Hwm) & 0,655919 & 0,089231 & 8,7169 & 1,185846 & 7,35078 & 0,000000 \\
\hline Fact (Him) & $-0,152698$ & 0,078665 & $-10,1226$ & 5,214814 & $-1,94112$ & 0,059890 \\
\hline Fact $(H t r)$ & 0,420306 & 0,085279 & 10,9452 & 2,220757 & 4,92857 & 0,000018 \\
\hline
\end{tabular}

a)

\begin{tabular}{|c|c|c|c|c|c|c|}
\hline \multirow[b]{2}{*}{$\mathrm{N}=41$} & \multicolumn{6}{|c|}{$\begin{array}{l}\text { Regression Summary for Dependent Variable: Fuel Consumption } \\
R=, 88817551 \mathrm{R} ?=, 78885574 \text { Adjusted } R ?=, 77774289 \\
F(2,38)=70,986 p<, 00000 \text { Std. Error of estimate: } 11,022\end{array}$} \\
\hline & Beta & $\begin{array}{l}\text { Std.Err. } \\
\text { of Beta }\end{array}$ & B & $\begin{array}{l}\text { Std.Err. } \\
\text { of B }\end{array}$ & $t(38)$ & p-level \\
\hline Intercept & & & 22,0 & 5,407294 & 4,082 & \\
\hline Fact (Hwm) & 0,603000 & 0,088005 & 8,01362 & 1,169546 & 6,851905 & 0,000000 \\
\hline Fact (Htr) & 0,406094 & 0.088005 & 10,57507 & 2.291724 & 4,614462 & 0,000044 \\
\hline
\end{tabular}

b)

\begin{tabular}{|c|c|c|c|c|c|c|}
\hline \multirow[b]{2}{*}{$\mathrm{N}=41$} & \multicolumn{6}{|c|}{$\begin{array}{l}\text { Regression Summary for Dependent Variable: Fuel Consumption } \\
R=, 92534460 \mathrm{R} ?=, 85626263 \text { Adjusted } R ?=, 84869751 \\
\mathrm{~F}(2,38)=113,19 p<, 00000 \text { Std. Error of estimate: } 9,0944\end{array}$} \\
\hline & Beta & $\begin{array}{l}\text { Std.Err. } \\
\text { of Beta }\end{array}$ & B & $\begin{array}{l}\text { Std.Err. } \\
\text { of B }\end{array}$ & $t(38)$ & p-level \\
\hline Intercept & & & 18,33154 & 4,507495 & 4,06690 & 0,000231 \\
\hline Run, $\mathrm{km}$ & $\overline{0,455196}$ & 0,064962 & 0,25455 & 0,036327 & 7,00709 & 0,000000 \\
\hline Fact (Hwm) & 0,672298 & 0,064962 & 8,93456 & 0,863321 & 10,34906 & 0,000000 \\
\hline
\end{tabular}

c)

Figure 5. Results of the construction of multi-factor models of the Fuel Consumption (Norma) MLT- 6 (a) three-factor model from the time of operation, b) two-factor model from the time of operation, b) two-factor model from the time of operation and Run.

\section{CONCLUSION}

A methodology for rationing the fuel consumption of the SSPS is proposed for use, which includes mechanisms for constructing identification models when identifying and using the most important data on the operating modes of the SSPS and additional operational factors. Fuel consumption is significantly affected by the type of specialized self-propelled rolling stock used. Thus, on the SSPS used in the economy of electrification and power supply of the AMD-1 type, the specific consumption of diesel fuel per trip is $9.8 \mathrm{~kg}$ per one total operating hour. SSPS used in the MTL-6 type track, the specific consumption of diesel fuel per trip is $11 \mathrm{~kg}$ for one total operating hour. When rationing the fuel consumption indicator, the mileage indicators of the SSPS and the operating modes when using the total operating time of the SSPS allows rationing to a precision of no more than $8 \%$. The use of reasonable normalized fuel consumption values allows to reduce fuel consumption by more than $30 \%$ over a period of three months by identifying and then eliminating unauthorized overspendings.

\section{REFERENCES}

Abas, M. A., Zainal Abidin, S. F., Rajoo, S., Martinez-Botas, R. and Ismail, M. I. (2017). Evaluation between engine stop/start and cylinder deactivation technologies under Southeast Asia urban driving condition. In: WCX ${ }^{\mathrm{TM}}$ 17: SAE World Congress Experience. SAE International. 
https://doi.org/10.4271/2017-01-0986.

Association of American Railroads. (2014). 2014 Q4 base. Retrieved March 18, 2021, from https://www.aar.org/wp-content/uploads/2017/12/AAR-RCAF-2014Q4-Submission-9-5-2014.pdf

Capuano, D., Costa, M., Di Fraia, S., Massarotti, N. and Vanoli, L. (2017). Direct use of waste vegetable oil in internal combustion engines. Renewable and Sustainable Energy Reviews, 69 (C), 759-770.

Gritsenko, A. V., Glemba, K. V. and Petelin, A. A. (2021). A study of the environmental qualities of diesel engines and their efficiency when a portion of their cylinders are deactivated in small-load modes. Journal of King Saud University - Engineering Science, 33 (1), 70-79.

Mitrofanov, A., Asabin, V. and Peshkov, A. (2020). Automation of diesel fuel consumption accounting on a special self-propelled rolling stock of Russian railways. E3S Web of Conferences, 157, 01002.

Mitrofanov, A., Tret'yakov, G. and Kopeikin, S. L. (2017). Predicting the energy-supply parameters for a transportation process based on multifactor models. Russian Electrical Engineering, 88 (3), 109-114.

Rymaniak, L., Daszkiewicz, P., Merkisz, J. and Bolzhelarskyi, Y. V. (2019). Method of determining the locomotive engine specific fuel consumption based on its operating conditions. AIP Conference Proceedings, 2078(1), 020053.

Tshizanga, N., Aransiola, E. F. and Oyekola, O. (2017). Optimisation of biodiesel production from waste vegetable oil and eggshell ash. South African Journal of Chemical Engineering, 23, 145-156. 